REMIGIUSZ RABIEGA

Wydział Prawa i Administracji Uniwersytetu Szczecińskiego

\title{
EUTANAZJA JAKO PROBLEM PRAWNY I ETYCZNY
}

Treść: Wstęp. - 1. Historyczne ujęcie eutanazji. - 2. Karnoprawna typizacja eutanazji. - 3. Etyczne problemy związane z eutanazją. - 4. Medyczne aspekty eutanazji. - 5. Zakończenie.

\section{Wstęp}

Księga Rodzaju mówi, że „Na początku Bóg stworzył niebo i ziemię", dzięki temu opisowi możemy poznać atrybuty Boga, wyłaniające się z obserwacji stworzonego przez Niego świta. W wielkim zamyśle ukształtowane są elementy - które niczym budowle wychodzące spod ręki architekta - mówią nam o Bogu, jako o Twórcy wszystkiego, co występuje we Wszechświecie. Wszystko, co istnieje - odnosi się do mocy, majestatu oraz troski i łaski, napawających każdy z tworów, rozmyślnie przez Boga wykreowanych. Jednym z takich składników jest (chyba najbliższe nam wszystkim) - życie ludzkie, stanowiące najcenniejszy dar, za który należy okazać ogromną wdzięczność i szacunek. Niestety dobro to, mające również status najcenniejszego dobra z punktu widzenia prawnego, nie zawsze jest przez nas otaczane wystarczającym szacunkiem. Niekiedy wręcz prowadzi do unicestwienia, wynikającego z zamierzonego postępowania ludzkiego.

Określenie „eutanazja” etymologicznie wywodzi się z języka gre-

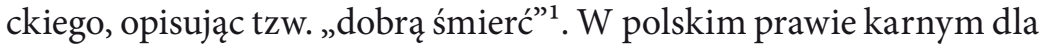

\footnotetext{
${ }^{1}$ Oprócz śmierci naturalnej w (czyli thalis), w tradycji greckiej wyróżniano też przedwczesną śmierć nieszczęśliwą (ker) oraz właśnie przedwczesną śmierć
} 
określenia zabójstwa eutanatycznego, nierzadko stosuje się zamiennie określenia: zabójstwo z litości, czy też zabójstwo na żądanie. Samo wyrażenie „zabójstwo” pełni tu niepoślednią rolę, która przypisuje czynowi sprawcy walor umyślności, stanowiącej jedno ze znamion konstytuujących omawiany typ czynu zabronionego pod groźbą kary $^{2}$. Jest to rezultatem wyraźnego oddzielania w języku prawniczym określenia „zabójstwo” (łączącego się z występowaniem zamiaru po stronie sprawcy), od „spowodowania śmierci” (które z założeń obecnego Kodeksu karnego ${ }^{3}$, polega na nieumyślnym wywołaniu skutku, wynikającego z przekroczenia reguł ostrożności wymaganych w danych okolicznościach) ${ }^{4}$.

Najprawdopodobniej pierwsze wzmianki o eutanazji pochodzą z V w. p.n.e., kiedy to grecki poeta Kratinos w jednej ze swoich komedii użył tego określenia na śmierć szybką i bezbolesną ${ }^{5}$. W starożytności filozofowie tacy, jak Arystoteles, Cicero, Platon, czy Seneka usprawiedliwiali eutanazję głównie jako metodę zakończenia agonii eutanaty, choć pitagorejczycy zdecydowanie sprzeciwiali się prawu człowieka do odbierania sobie życia. Zapewne pogląd ten wynikał z uznanego wówczas założenia, jakoby nie każde dobro prawne mogło być przez człowieka dowolnie rozporządzane. Życie ludzkie należy do najwyższych wartości i dlatego uzyskało status tzw. dobra bezwzględnie chronionego. Dlatego właśnie prawo karne zakazuje nieograniczonego dysponowania swoim życiem, jeśli określone zachowanie się miałoby naruszać to dobro. Groźba nadużyć w tej kwestii ma swoje podstawy chociażby w tzw. neoeutanazji, która od XVIII do XIX w. występowała w Japonii, jako odpowiedź na panujący ówcześnie głód.

łagodną, czy też bezbolesną (euthanatos). Zob. R. TokArczy , Prawo narodzin, życia i śmierci, Zakamycze 2000, s. 375.

${ }^{2}$ Chodzi tu o art. 150 k.k.

${ }^{3}$ Ustawa z dnia 6 czerwca 1997 r., Kodeks karny, Dz.U. z 1997, Nr 88, poz. 553.

${ }^{4}$ Zob. S. GLASER, Zabójstwo na żądanie (art. 227 k.k.), Warszawa 1936, s. 58; B. Górnicki, Nowe problemy etyki lekarskiej, Etyka 1(1975), s. 25; M. TARnAwsKi, Zabójstwa uprzywilejowane w ujęciu polskiego prawa karnego, Poznań 1981, s. 203.

${ }^{5}$ Zob. W. BoŁoz (red.), Między życiem a śmiercią. Uzależnienia, eutanazja, sytuacje graniczne, Warszawa 2002, s. 123. 
Dla zachowania jak najlepszej kondycji społeczeństwa zabijano od 10 do 25 procent noworodków ${ }^{6}$. Ten zmultiplikowany problem był już przeze mnie omawiany przy okazji zajmowania się właśnie dzieciobójstwem, które pozbawiając dziecko możliwości zmycia grzechu pierworodnego, skazuje jednocześnie noworodka na „wieczną śmierć”

Wielu autorów uważa, że określenie „eutanazja” wywodzi się z poglądów XIII wiecznego angielskiego franciszkanina i filozofa - Rogera Bacona. Nie brakuje też zwolenników przypisujących autorstwo tego pojęcia Françoisowi Baconowi w związku z jego pracą Novum Organum z 1620 r., gdzie autor stanął na stanowisku, że eutanazja stanowi humanitarny obowiązek każdego lekarza. Jego poglądy były jednak przez prawie dwa stulecia pomijane, choć w XVIII w. zyskały stosunkową popularność, by na powrót odejść w zapomnienie.

Karol Darwin w swojej publikacji z 1871 r.: O pochodzeniu człowieka i doborze $w$ odniesieniu do płci, wskazywał, że ochrona osób niepełnosprawnych oraz chorych fizycznie, czy psychicznie wynika jedynie z nabytego instynktu sympatii i współczucia, przeciwstawiając się jednak zasadzie przetrwania gatunku. Poglądy te zostały następnie recypowane przez nazistów i za sprawą niemieckich uczonych, jak K. Binding, czy A. Hoche doprowadziły do powstania idei „życia niegodnego życia” oraz „życia niewartego życia”. W ich mniemaniu osoby ciężko chore, poważnie niedorozwinięte psychicznie, czy kalekie powinny być ze społeczeństwa usuwane. W oparciu o te poglądy w latach 1939-1944 w III Rzeszy zlikwidowano dziesiątki tysięcy ludzi, uważanych za „nosicieli bezwartościowego życia”" .

Ustawy karne, regulujące porządek na ziemiach polskich na przestrzeni od końca XVIII do początku XX wieku ujmowały kwestię eutanazji w różny sposób, przyznając jej jednak ciężar gatunkowy

\footnotetext{
${ }^{6}$ Zob. M. Szeroczyńska, Eutanazja i wspomagane samobójstwo na świecie. Studium prawnoporównawcze, Kraków 2004, s. 28.

${ }^{7}$ Zob. R. Rabiega, O współdziałaniu w popełnieniu przestępstwa indywidualnego niewłaściwego typu uprzywilejowanego (uwagi na tle dzieciobójstwa w polskim prawie karnym), Ius Novum 1(2012), s. 115 i nast.; G. Williams, Świętość życia a prawo karne, Warszawa 1960, s. 13-14.

${ }^{8}$ Zob. M. TARNAWSKI, op. cit., s. 202.
} 
występku. I tak, przykładowo Kodeks karny austriacki wyłączał stosowanie zasady Ulpiana: Volenti non fit iniuria uznając, że życie ludzkie nie jest dobrem prawnym, co do którego eutanata ma pełne prawo odnośnie decyzyjności. Znamiona modalne w ustawie niemieckiej, czy rosyjskiej odnosiły się natomiast do konieczności wystąpienia poważnego, wyraźnego żądania (Niemcy) albo nalegania na przeprowadzenie eutanazji (Rosja) ${ }^{9}$.

Po odzyskaniu przez Polskę niepodległości rozpoczęto prace nad nowymi kodyfikacjami. W efekcie tego powstał Kodeks karny z 1932 r., w którym zdecydowano o uznaniu eutanazji za odrębny typ czynu zabronionego (delictum sui generis), który także w przypadku tylko usiłowania będzie karalny. W opisie znalazły się natomiast tak elementy przedmiotowe - jak żądanie śmierci, jak i podmiotowe współczucie dla zabijanego człowieka. Zasugerowany przez Sekcję Prawa Karnego Materialnego Komisji Kodyfikacyjnej RP kształt omawianego przepisu (art. 227 k.k. z 1932 r.) zachował się niemal w niezmienionej formie po dzień dzisiejszy.

Art. $150 \$ 1$ k.k. wskazuje na to, że odpowiedzialności karnej podlega osoba, która dopuszcza się zabójstwa człowieka na jego żądanie ${ }^{10}$ i pod wpływem współczucia dla niego; choć w wyjątkowych przypadkach sąd może zastosować nadzwyczajne złagodzenie kary, a nawet odstąpić od jej wymierzenia (art. $150 \$ 2$ k.k.).

\footnotetext{
${ }^{9}$ Zob. A. Medwid, M. Kober, Zabójstwo na żądanie, Prawo i życie 4(2000), s. 74-77.

${ }^{10}$ Pomimo tego, że zgoda na naruszenie dobra chronionego prawem w sposób klarowny stanowi znamię typu uprzywilejowanego, to jednak zachowanie się sprawcy pozostaje tu w zbieżności z określonym typem czynu zabronionego pod groźbą kary; nie jest to więc jakaś okoliczność ekskulpacyjna. Zob. E. Hryniewicz, Zgoda dysponenta dobrem prawnym na gruncie prawa karnego, w: R. Zawłocki (red.), Zgoda pokrzywdzonego, Warszawa 2012, s. 35 . O ograniczeniu autonomii jednostki w decydowaniu o własnym życiu zob. także: J. DŁugosz, Zgoda dysponenta dobrem prawnym w świetle regulacji konstytucyjnych. Rozważania na pograniczu dogmatyki konstytucyjnego prawa jednostki do samostanowienia o sobie i dogmatyki prawa karnego, w: R. Zawłocki (red.), Zgoda pokrzywdzonego, Warszawa 2012, s. 8 i nast.
} 
Pomijając możliwość wymierzenia za popełnienie takiego przestępstwa kary grzywny lub ograniczenia wolności w oparciu o art. 37a k.k., czy środków karnych, jak: zakaz wykonywania zawodu, obowiązek naprawienia szkody, nawiązkę albo świadczenie pieniężne, należy zwrócić uwagę na to, że explicite ustawodawca przewidział tu jako podstawową sankcję karę terminowego pozbawienia wolności w wymiarze od 3 miesięcy do lat 5.

Zabójstwo eutanatyczne jest przykładem zachowania, które generalnie jest przestępstwem powszechnym (poprzez działanie może być ono popełnione przez każdego), ale może także być przestępstwem indywidualnym właściwym, ponieważ w przypadku zaniechania (niezapobiegnięcia negatywnemu skutkowi) adresatem normy zakazującej będzie ten tylko, na kim ciążył prawny szczególny obowiązek, czyli gwarant (art. 2 k.k.). Przedmiotem rodzajowym i bezpośrednim ochrony/zamachu jest tutaj, rzecz oczywista, życie człowieka, które musi być zakończone na skutek zachowania, znamionującego się zamiarem, a zatem $\mathrm{z}$ punktu widzenia znamion strony podmiotowej musi wystąpić umyślność.

Warto zwrócić uwagę na wskazaną już możliwość dokonania zabójstwa eutanatycznego w formie działania (będącego zachowaniem w sensie pozytywnym), np. poprzez umyślne podanie zwiększonej (śmiertelnej) dawki leku albo w formie zaniechania (będącego zachowaniem w sensie negatywnym), gdy przykładowo lekarz lub inna osoba, na której ciąży prawny, szczególny obowiązek zapobiegnięcia określonemu skutkowi, nie podejmie powinności, której winno uczynić się zadość ${ }^{11}$. Jako przestępstwo materialne, narusza ono dobro

${ }^{11}$ Dodatkowo można przywołać podział na tzw. eutanazję czynną i bierną. W pierwszym przypadku mamy do czynienia $\mathrm{z}$ faktycznym udziałem eutanaty, który godzi się, czy wręcz żąda śmierci, gdyż nie ma dla niego żadnych szans na wyleczenie. Z kolei eutanazja bierna wyzuta jest z występowania decyzyjności przedmiotu czynności wykonawczej i dotycząc np. osób niepełnosprawnych (niemających zdolności do sensownej autodeterminacji), jest poza granicą usprawiedliwionego zachowania, nie mogąc być traktowana jako postępowanie moralnie dobre. Zob. A. LAUn, Współczesne zagadnienie teologii moralnej. Teologia moralna - zagadnienia szczegółowe, Kraków 2002, s. 311. 
prawne, przy czym do analizowanego skutku dojść musi w związku z wystąpieniem związku kauzalnego. To typ uprzywilejowany przestępstwa, które w ujęciu ciężaru gatunkowego jest uznawane za występek. Czas i miejsce nie zostały bezpośrednio przez normodawcę wskazane, dlatego też przyjąć należy, iż znamiona modalne odnoszą się do każdego czasu i każdego miejsca.

Typ określony w art. $150 \$ 1$ k.k. zawiera znamiona szczególne, których brak dekompletuje treść omawianego typu czynu zabronionego pod groźbą kary, przerzucając odpowiedzialność sprawcy w zakres normowania art. $148 \$ 1$ k.k. Zarówno żądanie pokrzywdzonego, jak i współczucie dla niego stanowią esencję eutanazji, dzięki której omawiany typ uznać można za jedno $\mathrm{z}$ negatywnych znamion przestępstwa zabójstwa w typie podstawowym (art. $148 \$ 1$ k.k.). Szczególne zabarwienie subiektywne, wyrażające się we współczuciu oraz żądanie (stanowiące swego rodzaju zgodę na naruszenie dobra prawnego) konstytuują zabójstwo eutanatyczne, choć - jak będzie o tym mowa poniżej (co zresztą wynika też z samej idei kryminalizacji zachowania przełamującego normę z art. $150 \$ 1$ k.k.) - nie są one wystarczające dla uznania eutanazji za zachowanie w pełni usprawiedliwione.

Ponieważ zabójstwo na żądanie stanowi przede wszystkim problem etyczny, nie można tracić z pola widzenia faktu, że etyka ta ma głównie powiązanie z zagadnieniami medycznymi. Przecież najczęstszym sprawcą eutanazji jest właśnie lekarz, który w trudnym, nierzadko agonalnym stanie swojego pacjenta - stara się mu ulżyć w bólu. Ten subiektywny stosunek do pacjenta nie powinien jednak zaważyć na pełnej ocenie sytuacji. Każdy lekarz, jeszcze przed podjęciem praktyki zawodowej zobowiązany jest do złożenia przysięgi Hipokratesa, zgodnie z którą podstawową zasadą działalności leczniczej jest sentencja: primum non nocere. Skoro zatem niezmienna już od 2500 lat reguła nakazuje przede wszystkim nieszkodzenie pacjentowi, to w żadnych warunkach nie można usprawiedliwiać odchodzenia lekarza od możliwości uleczenia chorego ${ }^{12}$. Przecież nawet w samej przysiędze Hipokratesa medyk zastrzega się: „,nikomu,

${ }^{12}$ Zob. R. Fenigsen, Eutanazja. Śmierć z wyboru?, Poznań 1997, s. 113. 
nawet na żądanie, nie dam śmiercionośnej trucizny, ani nikomu nie będę jej doradzał"13.

Z drugiej jednak strony trzeba zdawać sobie sprawę $\mathrm{z}$ faktu postrzegania eutanazji przez pryzmat nie stricte medyczny, a filozoficzny, czy teologiczny. Poglądy Kościoła, czy szerzej - religii, w istotny sposób kształtują obraz dóbr, w tym i dóbr prawnych, wpływając na osąd społeczeństwa w jego sferze etycznej, a to z kolei ma pośrednie znaczenie dla ustalania nowych norm prawnych, mających przecież to społeczeństwo chronić. Ponieważ w Polsce wiodącą religią jest wyznanie rzymsko-katolickie, przez wzgląd na ograniczone ramy przedmiotowego szkicu, skoncentruję się wyłącznie na optyce prezentowanej właśnie przez Kościół katolicki.

Omawiana religia w tradycyjny sposób popiera normy etyki hipokratejskiej, dla której życie ludzkie jest wartością najważniejszą. Skoro zatem uznaje się świętość każdego życia ludzkiego ${ }^{14}$, to unicestwienie tego dobra musi się wiązać z pewnego rodzaju potępieniem, przedstawiającym się w prawie karnym, jako określona reakcja na popełniony przez sprawcę czyn. Rzecz jasna, owa reakcja nie może być równoznaczna dla każdej sytuacji, bo przecież inny stosunek emocjonalny będziemy mieć do kogoś, kto zabił w oparciu o motywy zasługujące na szczególne potępienie, czy też ze szczególnym okrucieństwem, a innej skali ewaluacji przypisywać będziemy sprawcę nieumyślnego spowodowania śmierci, czy właśnie zabójstwa dokonanego na żądanie i pod wpływem współczucia dla (najczęściej) ciężko chorej osoby. Nie zmienia to jednak faktu, iż naruszenie dobra życia ludzkiego jest nieakceptowalne, bo przecież życie to zostało wykreowane na obraz i podobieństwo Boże.

W sytuacji, gdy przykładowo ktoś decyduje się targnąć na swoje życie, mamy do czynienia $z$ atakiem na dar, który został nam powierzony. Również jakakolwiek forma zamachu na cudze życie wykazuje najwyższy stopień społecznej szkodliwości czynu, gdyż - jak już była

\footnotetext{
${ }^{13}$ M. Hebda, Prawne i moralne aspekty eutanazji, Rzeszowskie Zeszyty Naukowe. Prawo - Ekonomia, 2001, tom XXX, s. 312.

${ }^{14}$ G. Williams, op. cit., passim.
} 
o tym mowa na początku - ludzkie życie stanowi wartość chronioną w zakresie bezwzględnym, co oznacza, że nawet w najtrudniejszych chwilach nie możemy swobodnie decydować o swoim ostatecznym losie, albowiem (prócz reperkusji etycznych) zachowanie takie spotka się z odpowiednią reakcją prawnokarną. Na powyższy aspekt w $\mathrm{V}$ w. n.e. wyraźnie zwracał uwagę św. Augustyn, którego stanowisko zostało potwierdzone w przemówieniu papieża Piusa XII z 29.10.1951 r., gdzie podniesiono, że „każda istota ludzka wywodzi swoje prawo do życia przede wszystkim od Boga, a nie od rodziców czy społeczeństwa lub innej władzy ludzkiej. Nie istnieje więc żadna władza ludzka, żadna przesłanka medyczna, eugeniczna, społeczna, ekonomiczna czy moralna, która stanowiłaby legalny tytuł prawny dla bezpośredniego i zamierzonego zniszczenia niewinnego życia ludzkiego"15. W podobnym tonie Kościół wypowiada się w stosunku do zabójstwa eutanatycznego, o czym świadczy stwierdzenie, że: „jesteśmy tylko zarządcami, a nie właścicielami życia, które Bóg nam powierzył. Nie rozporządzamy nim"16.

Kościół katolicki twardo stoi na stanowisku, że eutanazja (rozumiana także jako swego rodzaju pomoc do samobójstwa ${ }^{17}$ ), narusza jedną z kardynalnych zasad, ofiarowanych nam w Dekalogu, a mianowicie - przykazanie V, zakazujące zabijania. Brak zgody na jakiekolwiek pozbawienie człowieka życia wynika m.in. z promulgowanej 5.05.1980 r. przez Jana Pawła II Deklaracji na temat eutanazji. W Deklaracji tej czytamy, że prawo do życia jest niezbywalne i stanowi najwyższe dobro, którego jakikolwiek relatywizm nie podlega w ogóle dyskusji. Stanowi się, iż „nikt nie ma prawa pozbawiać życia niewinnego człowieka, niezależnie od tego, czy chodzi o płód, embrion, dziecko, dorosłego, czy starca, nieuleczalnie chorego, czy

\footnotetext{
${ }^{15}$ A. Turek, J. Turek, W poszukiwaniu kodeksu bioetycznego, Prawo i Życie 1(2000), s. 26; M. SzeroczyńsKA, op. cit., s. 71.

${ }^{16}$ Katechizm Kościoła Katolickiego, Poznań 1994, s. 518.

${ }^{17} \mathrm{Z}$ punktu widzenia polskiego prawa karnego wskazać trzeba, że jest to swego rodzaju wykładania rozszerzająca, ponieważ polski ustawodawca traktuje tego rodzaju zachowanie (pomoc do samobójstwa), jako odrębny typ czynu zabronionego, opisany w art. 151 k.k.
} 
umierającego. Nikomu nie wolno dokonać aktu eutanatycznego wobec siebie oraz wobec osoby, za którą jest odpowiedzialny, nie wolno nawet na taki akt wyrazić zgody”. Dokument ten zawiera również swoją definicję eutanazji, rozumianą jako: „działania lub wstrzymanie się od działania powodujące śmierć z samej swej natury lub dokonane $\mathrm{w}$ intencji spowodowania śmierci w celu wyeliminowania wszelkiego bólu"18. Jak zatem widać - jakiekolwiek zachowanie zmierzające do pozbawienia człowieka życia (rozumianego także szeroko, jako prawo do życia) nie znajduje akceptacji w tradycyjnej nauce Kościoła ${ }^{19}$.

Nie zmienia to jednak faktu, że także niektórzy przedstawiciele tego Kościoła mają odmienne zdanie i otwarcie je manifestują. Przykładowo jeden ze znanych włoskich kardynałów - Carlo Maria Martini - w stosunku do przypadku odmówienia dokonania pochówku dla człowieka wielokrotnie domagającego się skrócenia jego mąk stwierdził, że każdy przypadek winien być rozpatrywany indywidualnie i to z głęboką rozwagą, by prawo do życia było równocześnie prawem do godnego życia; przy czym sytuacja beznadziejności w walce o uratowanie ludzkiego życia powinna być sygnałem do złagodzenia optyki na rygoryzm oceniania zabójstwa z litości. To właśnie w tym kontekście przywołana Deklaracja wskazuje na to, że „kiedy zbliża się śmierć i już żadna terapia nie może jej zapobiec, wolno postanowić w sumieniu swoim o zaprzestaniu podejmowania dalszych prób leczenia, jeśli przyczynią się one wyłącznie do przedłużenia pełnego cierpienia życia; nie odstępując jednakże od

\footnotetext{
${ }^{18}$ Cytowane za: M. Filar, Lekarskie prawo karne, Zakamycze 2000, s. 311; zob. także: M. SzeroczyŃsKa, op. cit., s. 71-72.

${ }^{19}$ Potwierdzeniem tych tez jest typizacja kanonu 1397 Kodeksu Prawa Kanonicznego z 25 stycznia 1983 r., która została omówiona przez ks. G. Leszczyńskiego. Zob. idem: Eutanazja. Grzech i przestępstwo, Prawo Kanoniczne 56(2013) nr 2, s. 101-103. Autor ten podnosił nadto, że „uznanie prawa pacjenta do eutanazji oznacza tak naprawdę uznanie prawa do samobójstwa jako wyraz jego wolności i możności decydowania o sobie”, op. cit., s. 96.
} 
kontynuowania świadczenia normalnych zabiegów opiekuńczych, które jesteśmy winni każdemu choremu"20.

Uwagę należy wreszcie zwrócić na kwestię kryminalizacji zabójstwa eutanatycznego. Już wcześniej wykazane argumenty wynikające z dogmatów wiary katolickiej nie są przecież równoznacznie uznawane przez całe społeczeństwo, a tym bardziej przez przedstawicieli porządków prawnych różnych, charakterystycznych dla odmiennych państwowości. Ratio legis pociągania do odpowiedzialności za powodowanie śmierci w oparciu o żądanie i współczucie względem przedmiotu czynności wykonawczej ma zgoła inne uzasadnienie, aniżeli motywy przeciwników wiązania eutanazji ze stosowną penalizacją. W sporze przywołuje się tak treści moralne, jaki i medyczne, czy prawne.

Patrząc na sprawę z punktu widzenia przeciwników legalizowania eutanazji w pierwszej kolejności możemy spojrzeć na aspekt etyczny. Powyżej wielokrotnie przywoływałem racje wyrażane przez przedstawicieli Kościoła katolickiego, którzy życie traktują jako świętość i dar od Boga, stanowiący jednocześnie największe bogactwo, nie powierzone nam jednak w pełni na własność. Człowiek w swojej znikomości nie może decydować o tym, kiedy linia jego życia ulegnie przerwaniu, ponieważ bardzo często decyzja ta może być omyłkowa. Dlatego właśnie, skoro życie ofiarowane jest nam przez Boga, tylko

${ }^{20}$ M. SzeroczyńsKa, op. cit., s. 75. Rzeczony wątek miał swoją kontynuację także w encyklice Evangelium Vitae, podpisanej przez Jana Pawła II 25.03.1995 r. Potępiając tzw. „kulturę śmierci” Papież pisze: „to, co mogłoby się wydawać logiczne i humanitarne, przy głębszej analizie okazuje się absurdalne i nieludzkie. Stajemy tu w obliczu jednego z najbardziej niepokojących objawów kultury śmierci, szerzącej się zwłaszcza w społeczeństwach dobrobytu, charakteryzujących się mentalnością nastawioną na wydajność, według której obecność coraz liczniejszych ludzi starych i niesprawnych wydaje się kosztowna i uciążliwa”. Zupełnie inaczej przedstawiane jest tutaj „łagodzenie cierpienia”, albowiem w tej materii ustalono, że „gdy zagraża śmierć, której w żaden sposób nie da się uniknąć przez zastosowanie dostępnych środków, wolno w sumieniu podjąć zamiar niekorzystania z leczenia, które może przynieść tylko niepewne i bolesne przedłużanie życia, nie przerywając jednak zwyczajnej opieki, jaka w podobnych wypadkach należy się choremu”. JAN PAwEŁ II, Evangelium Vitae, Kraków 1995, s. 932. 
On może zdecydować o jego doczesnym zakończeniu ${ }^{21}$. W powiązaniu $z$ tym podłożem pojawia się jeszcze etyka ściśle wiążąca się $\mathrm{z}$ wykonywaniem zawodu przez lekarza ${ }^{22}$. Osoby wyznające zasady płynące z przysięgi Hipokratesa uważają (o czym już uprzednio wspomniałem), że medyk w żadnym wypadku nie może przyłożyć ręki do śmierci człowieka. Nie zawsze jednak sprawa przedstawia się klarownie, przedstawiając wyłącznie kolor czarny albo biały ${ }^{23} . \mathrm{Na}$ tym tle wypowiadał się również papież Paweł VI, który to zaznaczył, iż „ta sama cecha świętości życia, która zabrania lekarzowi zabijać, dyktuje mu zarazem obowiązek zastosowania wszystkich dostępnych jego umiejętnościom pomocy do walki przeciw śmierci. Lecz to nie obowiązuje lekarza do tego stopnia, by stosował do przedłużenia życia wszelkie techniczne zdobycze, jakie dziś oferuje niestrudzenie twórcza wiedza. W wielu bowiem wypadkach, czyż narzucanie reanimacji wegetatywnej nie byłoby bezużytecznym torturowaniem w ostatniej fazie nieuleczalnej choroby? Zadaniem lekarza jest więc raczej zmierzać do uspokojenia cierpień, niż do ostatecznych granic, bez względu na środki i możliwości usiłować przedłużyć życie, które już w pełni nie jest ludzkie i zmierza ku swemu naturalnemu rozwiązaniu, do godziny, jakiej się nie wybiera i która jest święta przez spotkanie duszy ze swym Stwórcą po przekroczeniu drogi cierpień, dającej uczestnictwo w cierpieniu Chrystusa. Również więc w tym powinien lekarz szanować życie"24.

Inna perspektywa pojawia się przy rozpatrywaniu okoliczności prawnych. Co prawda większość państw wprowadziła do swych

${ }^{21}$ Z. Golı́́ski, Zabójstwo z litości w świetle etyki katolickiej, Lublin 1937, s. 19; W. Szкотnicki, A. KACzor, Eutanazja - aspekty społeczno-prawne, Prokuratura i Prawo 2(1997), s. 55.

${ }^{22}$ B. Popielski, Medycyna i prawo, Warszawa 1968, s. 331; idem, Etyczne i prawne zagadnienia medycyny współczesnej, w: J. Fiema, W. Gutekunst, S. Hubert, Księga pamiątkowa ku czci prof. W. Świdy, Warszawa 1969, s. 281; W. Rudowski, Złożony problem, Prawo i Życie 6(19730, s. 6.

${ }^{23}$ Z. Sobolewski, Życie nie warte cierpienia, Palestra 6(1974), s. 80.

${ }^{24}$ J. Buxa коwsкi, Chrześcijańska etyka lekarska, Chrześcijanin w świecie 3(1976), s. 19-20. 
kodeksów karalny typ czynu zabronionego, odnoszący się do eutanazji, lecz znowu nie musi to przemawiać za słusznością tego posunięcia. Teoretycznie uznać można że prawodawca (z założenia posiadający przymiot racjonalności) ma swobodę w decydowaniu o tym, które zachowania wykazują w jego ocenie tak wysoki stopień społecznej szkodliwości czynu, by za to właśnie zachowanie karać. Pamiętać jednakże należy, iż prawo jest jednak tworzone przez ludzi, równie omylnych, jak my wszyscy. W związku z tym trudno jednoznacznie opowiedzieć się za jedną z możliwości rozgraniczanych właśnie przez cezurę legalności lub zabronienia, gdyż sporów na tej płaszczyźnie jest bardzo wiele, przez co osiągnięcie zadowalającego kompromisu okazuje się być póki co - niemożliwe.

Kolejnym elementem ewaluacyjnym może być wzgląd medyczny, z którym łączy się stan psychicznej równowagi eutanaty. Nierzadko jest przecież tak, że osoba dowiadująca się o poważnej chorobie, czy wręcz beznadziejnym stanie zdrowia - popada w depresję. O ile chęć walki o swoje życie może okazać się istotnym motorem do zyskiwania dodatkowych sił, wewnętrznie wspierających chorego, o tyle stan przygnębienia może wywoływać dalsze patologie, prowadzące do tak głębokiego zniechęcenia, że w przypływie obojętności pacjent może prosić (żądać) o śmierć także wtedy, gdy nie w pełni będzie on uświadamiał sobie wagę przedsięwziętych poczynań. Nie trudno dopuścić w wyobraźni scenariusz prowadzący do nagłego wzrostu liczby zabójstw eutanatycznych wywołanych stanem depresyjnym, w przypadku legalizacji tego typu zachowania. Dodatkowo zdawać sobie należy sprawę z nieodwracalności dokonania zabójstwa $\mathrm{z}$ litości. Sprawa jest tutaj równie skomplikowana, jak w przypadku zwolenników i przeciwników stosowania kary śmierci. W obu przypadkach czyn ten nie będzie mógł być cofnięty, co może okazać się szczególnie problematyczne w kontekście istotnej zmiany sytuacyjnej. Niewykluczone, że diagnoza lekarza mogła wymijać się z prawdą i jego przewidywania odnośnie do krótkiego prognozowanego życia nie są wcale słuszne. Ponadto medycyna rozwija się w oszałamiającym tempie, przez co trwanie w chorobie może okazać się decyzją dającą możliwość do skorzystania z nowych skutecznych metod, 
niestosowanych co prawda dziś, ale być może dostępnych już za kilka miesięcy. W dodatku opieka paliatywna oraz hospicja wspierające nie tylko osoby chore, ale także ich rodziny, rozwijają się równie prężnie, dając dziś niepomiernie większą ulgę, aniżeli występowało to jeszcze kilka lat temu ${ }^{25}$.

$\mathrm{Na}$ zakończenie tych opozycyjnych względem dekryminalizacji eutanazji ustaleń, wskazać jeszcze trzeba na wątek utylitarny. Niejednokrotnie przywołuje się tutaj złe doświadczenia holenderskie, zgodnie z którymi badania statystyczne wykazują na ogromną ilość stosowanych tam zabiegów prowadzących do śmierci na żądanie, co nierzadko rodzi podejrzenie o stosowanie nadużyć w tym temacie. Niektórzy otwarcie posądzają lekarzy o to, że stosując tę metodę mogą w łatwy sposób zabić kogoś tak naprawdę z absolutnie niskich pobudek. Innym rodzajem nieprawidłowości mogą być zabójstwa względem osób w różny sposób dyskryminowanych ze względu na rasę, status społeczny, wykształcenie, czy inteligencję (w tym także osób niepełnosprawnych oraz chorych psychicznie). Takie zachowanie w istotny sposób może zachwiać poczuciem stabilności i zaufania, jakim zwyczajowo darzy się lekarzy ${ }^{26}$; a nadto może zmniejszyć rozwój poszukiwań naukowych, dążących do znalezienia środków skutecznie niwelujących ból i pomagających w chorobach, które obecnie są nieuleczalne ${ }^{27}$. Co więcej, w wydanym przez holenderską Komisję Rządową w 1991 r. sprawozdaniu potwierdziły się przypuszczenia przeciwników legalizacji eutanazji. Okazało się, że na tym polu dokonywano zatrważających nadużyć, prowadzących w głównej mierze do wykonywania tysięcy zabiegów niedobrowolnych, prócz których stwierdzono jeszcze całe mnóstwo innych uchybień, sprzeciwiających

\footnotetext{
${ }^{25}$ K. de Walden-GaŁuszko, Podstawy opieki paliatywnej, Warszawa 2004, s. 17.

${ }^{26}$ T. Kielanowski, Problem niepotrzebnego cierpienia. O niepotrzebnym cierpieniu, rodzonym przez postępy nauk medycznych, w: Z. Szawarski, W kręgu życia i śmierci: moralne problemy medycyny współczesnej, Warszawa 1987, s. 113.

${ }^{27}$ A. Witek, Problem eutanazji, Kraków 1950, s. 79.
} 
się wyraźnym wytycznym, które (przynajmniej z założenia) miały być przez lekarzy respektowane ${ }^{28}$.

W opozycji do przywołanych powyżej argumentów powstają ruchy na rzecz legalizacji eutanazji. Standardowo odnoszą się one nie tyle do wartości ludzkiego życia, co do prawa do śmierci, która winna nadto być śmiercią godną. Przedstawiciele tej frakcji optują za tym, by prawo o samostanowieniu miało większą wartość, aniżeli prawo pozytywne, oddawane w nasze ręce przez ustawodawcę. Nierzadko podnosi się, że skoro samobójstwo nie jest przez prawo penalizowane, to dlaczego decyzja, dotycząca zakończenia agonii ma prawną legitymizację.

Od razu trzeba tutaj zwrócić uwagę na to, że wspomniane ruchy opierają się na dwóch, zgoła odmiennych przesłankach. Jedni poszukują prawa do eutanazji w aspekcie wolnościowym, a inni w eksterminacyjnym. Pierwszy z nich uderza przede wszystkim w ludzkie współczucie, starając się wykazać, iż śmierć w przypadku nieuleczalnie chorego, którego stan jest najczęściej beznadziejny, to prawdziwe wybawienie, dające ukojenie w bólu fizycznym i psychicznym. Przykładowo T. Cyprian stwierdził, że: „gdy człowiek nie może już komunikować się z otoczeniem i rozpada się więź łącząca działania poszczególnych jego organów, wiadomo zaś, że więź ta się nie odtworzy, przedłużanie wegetacji poszczególnych organów ciała ludzkiego nie należy do obowiązków najsumienniejszego nawet lekarza kierującego się przysięgą Hipokratesa"29.

O ile tę argumentację można jeszcze w pewnych sytuacjach uznać za słuszną, to zdecydowane obiekcje powinny się pojawić w związku z przesłankami przytaczanymi przez zwolenników nurtu eksterminacyjnego. W dobie permanentnego dążenia do ideału i wiecznej młodości - naturalizm zdaje się być brzydotą w czystej formie. To dlatego ciągle staramy się przedłużyć atrakcyjny wygląd, a myśl chociażby o starzeniu przez niektórych zdaje się być wyzuta poza granicę świadomości. W tym kontekście pewna grupa osób chciałaby wyeliminować ze społeczeństwa to, co niepożądane. Wśród

\footnotetext{
${ }^{28}$ W. Szкотnіскі, Za i przeciw legalizacji eutanazji, Palestra 5-6(1997), s. 17.

${ }^{29}$ T. Cyprian, O eutanazji niech decyduje sąd, Prawo i Życie 10(1973), s. 8.
} 
właśnie takich fragmentów rzeczywistości znajdują się osoby stare, chore, czy niedorozwinięte, które w ujęciu zwolenników eutanazji eksterministycznej powinny być czym prędzej usunięte. Element ten, jako składowa nieodzownych skojarzeń z bestialskimi praktykami nazistów, został przez zwolenników zabójstwa eutanatycznego w Holandii dosyć szybko zakamuflowany, jednakże nie zniknął on zupełnie, po to, by „nie zniechęcać tych, którzy wierzą w udoskonalenie ludzkości poprzez eksterminację cherlaków i innych jednostek małowartościowych"30.

Oczywiście praktyki takie mogą w rzeczywistości osiągnąć zupełnie przeciwny od zamierzonego rezultat. Teoretycznie większość zwolenników ruchu legalizującego eutanazję w duchu wolnościowym, daje nam prawo do decydowania o tym, kiedy i w jaki sposób chcemy „odejść", aczkolwiek z czasem takie przyzwolenie może się obrócić przeciwko nam. Niewykluczone, że dekryminalizacja eutanazji sprowadzi na nas wręcz przymus umierania i zamiast przyznawania praw, wiązać się będzie z odbieraniem prawa do życia ${ }^{31}$, gdy tylko „właściwa” osoba o tym zdecyduje.

Z punktu widzenia medycznego znowu należy się zastanowić w rzeczonym temacie nad możliwościami, jakie stoją przed lekarzem. Niekiedy zdarza się na przykład, że przed lekarzem pojawia się dylemat, którego z pacjentów w danym przypadku podtrzymywać przy życiu. Wiadomym jest, że proces sztucznego utrzymania życia wiąże się z koniecznością stosowania wielu skomplikowanych i drogich maszyn, na których nadmiar szpitale z pewnością nie mogą narzekać. Co więc zrobić, gdy na sali znajduje się dwóch agonalnie chorych, a tylko jeden sprzęt nadający się do udzielenia pomocy, przy czym pomoc ta musi być stała. Teoretycznie można się powołać na określony w art. $26 \$ 5$ k.k., ściągający z lekarza odpowiedzialność za

\footnotetext{
${ }^{30}$ R. Fenigsen, op. cit., s. 131.

${ }^{31}$ Ibidem, s. 136.
} 
nieudzielenie pomocy ${ }^{32}$, jednakże na jakich zasadach dokonywana jest taka ocena „ważąca” na szali życie pacjentów?

Wypadałoby jeszcze zastanowić się nad tym, jak zagadnienie eutanazji postrzegane jest w Polsce. Otóż w naszym kraju, gdzie zdecydowana większość populacji przyznaje się do wyznawania wiary katolickiej, jeszcze przez wiele lat trudno będzie sobie wyobrazić ustawodawstwo niekarzące zabójstwa z litości. Pamiętajmy, że prawo jest stanowione dla społeczeństwa, więc w przeważającej części wyraża ono system wartości i zapatrywania przez to społeczeństwo przyjęte. J. Dziedzic przeprowadzał badania, mające ukazać stosunek studentów medycyny oraz pielęgniarek do eutanazji. W obu przypadkach większościowo opowiadano się przeciwko legalizacji eutanazji, gdyż przyzwolenie na zabójstwo na żądanie mogłoby w znacznym stopniu ograniczyć zaufanie do lekarzy i szpitali w ogóle. Take poglądy reprezentowały głównie osoby, które w swej ocenie należą do osób głęboko religijnych. Respondenci przyznający się do płytszych korzeni w wierze odpowiadali, że eutanazja może być w ich ujęciu drogą uśmierzającą ból i skracającą cierpienie. Osoby te twierdziły, iż zupełnie właściwe jest dokonywanie eutanazji na innych osobach gdy wyrażą na to zgodę (20\% ankietowanych), a dodatkowe $18 \%$ badanych odpowiadało, że tym bardziej pożądana jest możliwość skrócenia własnego życia ${ }^{33}$.

Jak wiadomo wszelkie kwestie tanatologiczne, takie jak kara śmierci, samobójstwo, aborcja, czy właśnie eutanazja są tematami nader trudnymi, w których stanowiska najczęściej są skupione wokół jednego lub drugiego bieguna. Świat gna do przodu, a wraz z nim poglądy ludzi się zmieniają. Tym niemniej za legalizacją eutanazji zwyczajowo opowiadają się raczej ludzie młodzi, dla których widmo

\footnotetext{
${ }^{32}$ Pomijam tutaj głębsze rozważania nad zbędnością tego właśnie przepisu w Kodeksie karnym. Już z logicznego punktu widzenia jasnym jest, że nie można od człowieka wymagać czegoś, co jest poza zakresem jego możliwości. Reguła ta wypływa jasno z łacińskiej paremii impossibilium nulla obligatio est.

${ }^{33}$ J. Dziedzic, Eutanazja a religijność, Kraków 1999, s. 182-185; idem, Spór o eutanazję, Kraków 2005, passim.
} 
śmierci jest jeszcze bardzo odległe. Nasze społeczeństwo, wychowane w etyce Kościoła katolickiego w dużej mierze rozumie znaczenie przykazania „nie zabijaj” i pod tę normę włącza także rzecz oczywista - umyślną - eutanazję, stojącą na równi z każdym innym rodzajem zabójstwa. Ponadto Polacy nadal należą do nacji osadzonych na raczej średniej stopie życiowej, przez co proceder zabójstwa na żądanie nie pochłania nas tak bardzo, jak mieszkańców Europy zachodniej.

Oczywiście poglądy na zagadnienie zabójstwa eutanatycznego mogą być różne, nie zmienia to jednak faktu, że najczęściej żądanie chorego o zakończenie jego życia jest tylko rodzajem wołania o pomoc. Anormalna sytuacja motywacyjna pacjenta, jego ból, stres i bardzo często osamotnienie nie przemawiają za racjonalnością jego poczynań, a wręcz mogą niekiedy poddawać je nawet w wątpliwość ${ }^{34}$. W dobie rozwijającej się opieki paliatywnej, ciągłych postępów na polu farmacji należy się zastanowić, czy pozbawienie życia drugiego człowieka (nawet w ramach współczucia i występującego żądania) jest faktycznie drogą najwłaściwszą? Każdy przypadek musi być oceniany indywidualnie i zgodnie z sumieniem, tyle że - póki co - sumienie to $\mathrm{w}$ razie decyzji o dokonaniu eutanazji będzie rozliczane przez prawo, którego jedną z głównych funkcji jest zagwarantowanie bezpieczeństwa dobrom o szczególnej wartości, a życie (jak wiadomo) jest w tej materii wartością bezwzględnie nadrzędną.

W ramach podsumowania pozwolę sobie przytoczyć słowa R. Fenigsena, który napisał, że „Granica się przesuwa, ale zawsze gdzieś musi przebiegać, pytanie tylko, gdzie? I zwłaszcza: czy sprawa życia i śmierci człowieka należy jeszcze do zakresu sacrum, czy też jest to coś, czym wolno manipulować? Idea eutanazji jest wyborem na rzecz tej ostatniej tezy i w ten sposób popadamy w szczególne samozaprzeczenie: istota, która pretenduje do tego, by zawładnąć wszechświatem, kończy tym, że sama siebie uznała za disposable product, artykuł, który wyrzuca się po użyciu”35.

\footnotetext{
${ }^{34} \mathrm{~W}$ podobnych kryteriach ocenia się też szczególną sytuację matki, która decyduje się za zabicie swojego nowonarodzonego dziecka.

${ }^{35}$ R. Fenigsen, op. cit., s. 102-103.
} 


\section{Euthanasia, as a legal and ethical issue}

In this article, the author discusses the issue of euthanasia mainly from the point of view of Polish criminal law and in terms of ethical standards. These standards significantly shape the society, affecting also on the appearance of the legislation. Since the legislature has decided to describes the type of euthanasia (murder at the request and under the influence of compassion) in the penal code, it must mean, that such behavior despite (it might seem) a manifestation of mercy - must demonstrate a certain degree of social harm. Moreover, this act forbidden under threat the penalty, confirms the limitations in the disposal of legal goods, which have an universal character. This means that even in the case of agreement (here even required or demanded from the killed person) offender cannot be inculpabled.

In addition to the legal nature, euthanasia shows primarily relationship with an ethical realm. Both: the Hippocratic Oath and the science of the Catholic Church, considers human life as the most important good. This means that nobody is allowed to decide on taking someone else's life. Legalized euthanasia may therefore constitute a significant threat, so be sure to think about where is the line between sacrum and profanum.

SŁOWA KLUCZOWE: eutanazja, prawo karne, etyka, medycyna.

KEY wORDS: euthanasia, criminal law, ethics, medicine.

Nota o Autorze:

Mgr Remigiusz RABiEgA - asystent w Katedrze Prawa Karnego Wydziału Prawa i Administracji Uniwersytetu Szczecińskiego. 